
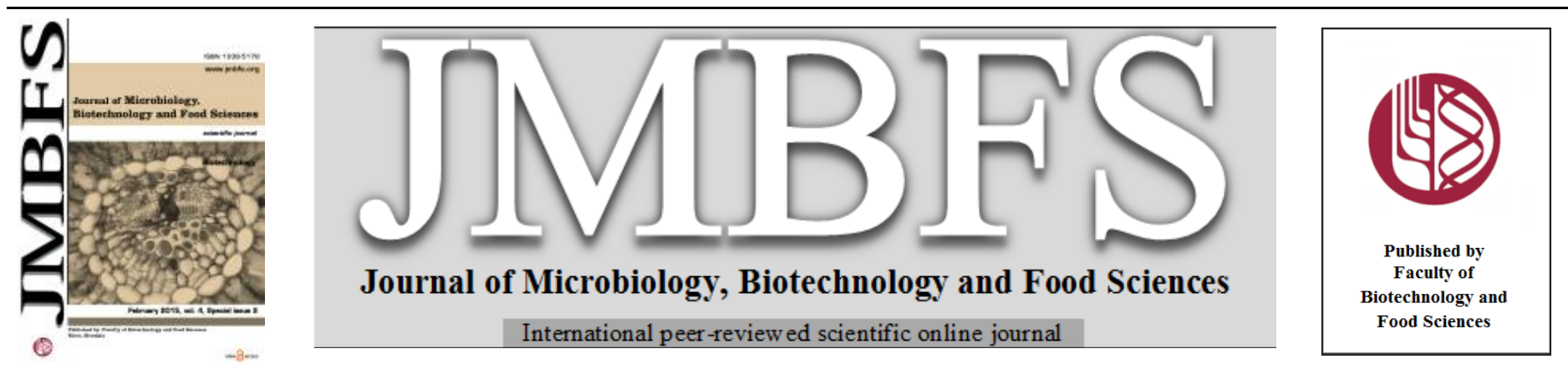

\title{
THE USE OF DIFFERENT PROTEASES TO HYDROLYZE GLIADINS
}

\section{Peter Socha $*^{1}$, Barbara Mickowska², Dana Urminskál, Kvetoslava Kačmárovál}

Address(es): : Ing. Peter Socha, PhD.,

${ }^{1}$ Slovak University of Agriculture, Faculty of Biotechnology and Food Sciences, Department of Biochemistry and Biotechnology, Tr. A. Hlinku 2, 94976 Nitra, Slovak Republic, phone number: +421-37-641-4598.

${ }^{2}$ Małopolska Centre of Food Monitoring, Faculty of Food Technology, University of Agriculture in Krakow, Balicka 122, $30-149$ Krakow, Poland.

*Corresponding author: peter.socha@uniag.sk

doi: 10.15414/jmbfs.2015.4.special2.101-104

ARTICLE INFO

Received 20. 11. 2014

Revised 2. 12. 2014

Accepted 5. 1. 2015

Published 2. 2. 2015

Regular article open $\odot$ access

\begin{abstract}
Gliadins represent alcohol-soluble fraction of wheat storage proteins which is responsible for development of celiac disease. The only and effective treatment for celiac disease is strict adherence to a gluten-free diet excluding any food made with wheat, as well as rye, barley and possibly oat flour. Enzymatic modification of wheat gliadins seems to be an alternative method for decreasing of celiac activity. The aim of our study was a trial of enzymatic modification of wheat gliadins using fungal (Aspergillus sp., Aspergillus oryzae, Aspergillus niger) and bacterial (Bacillus licheniformis, Bacillus stearothermophilus, Bacillus thermoproteolyticus, Streptomyces griseus) proteases. The reaction was performed up to $60 \mathrm{~min}$, stopped by addition of appropriate synthetic inhibitor and products of limited proteolysis were analyzed by SDS-PAGE method. From fungal proteases most effective proteolytic activity was observed using acid proteinase from $A$. niger since wheat gliadins and low molecular weight peptides were completely degraded. Bacterial proteases form B. licheniformis and B. thermoproteolyticus acted very effective and as the result of hydrolysis, the products of lower molecular weight $(<15 \mathrm{kDa})$ occurred. Most of the wheat gliadins were susceptible to proteolysis by examined bacterial enzymes (exception were protease from B. stearothermophilus and S. griseus). Although wheat gliadins are susceptible to enzymatic degradation, further analysis (e.g. immunochemical or mass spectrometry) are desirable to confirm if the products of proteolysis have lost or at least partially decrease their celiac activity.
\end{abstract}

Keywords: Gliadins, proteases, celiac disease

\section{INTRODUCTION}

Wheat proteins play an important role in the determining both nutritional and functional properties of derived foods. Based on their different solubility, wheat proteins can be classified into water/salt-soluble albumins and globulins, alcoholsoluble gliadins, and the glutenins soluble in diluted acid/base solutions (Mamone et al., 2011). Wheat gliadins, traditionally subdivided into $\alpha / \beta-, \gamma$ - and $\omega$-fractions according to their mobility in polyacrylamide gels, represent monomeric polypeptides with molecular weight approx. 28-50 kDa (Wieser, 2007; Vaccino et al., 2009). They are rich in glutamine (35\%) and proline (15\%) which makes them highly resistant to proteolytic degradation within the gastrointestinal tract causing the development of celiac disease (Gregorini $\boldsymbol{e t}$ al. 2009). As a result, many long peptides ( $>20$-mers) persisted during digestion in small intestinal lumen and are only partially hydrolyzed by brush-border membrane exopeptidases. These peptides (mostly 33-mer from $\alpha$-gliadin) are deamidated by transglutaminaze 2 (TG2) resulting in Th1 cell proliferation in the gut mucosa of celiac patients (Siegel et al., 2006). Thus eliminating the amount of Pro- and Gln-rich immunotoxic peptides in the small intestine can have a significant therapeutic potential.

Currently the only and effective treatment for celiac disease is a strict life-long gluten free diet forbids any foods containing wheat gliadins and corresponding proteins from rye, barley and possibly oat (Zingone et al., 2010). In recent years, several attractive therapeutic strategies have been arisen (see review Makharia, 2014) from which enzyme therapy is proposed as one of the future options to reduce or even eliminate the celiac-active properties of gliadins. The enzyme therapy investigated two different approaches focused on microbial prolylendopeptidases (PEPs) (Marti et al., 2005; Stepniak et al., 2006; Ehren et al., 2009) and naturally-evolved glutenases (Stenman et al., 2009, 2010). The PEPs family has ability to cleave internal proline residues within a peptide sequence. Although, most of PEPs are irreversibly inactivated by gastric enzymes and acidic $\mathrm{pH}$, it is unable to cleave some of Pro-rich peptides, such as the 33-mer from $\alpha$-gliadin, it could simplify gluten structure and texture using encapsulation of PEP/s in order to protect them (Solid, Khosla, 2005). On the other side, glutenases from germinating cereals evolutionarily selected for their cleavage of glutamine residuses are also highly efficient in degradation wheat gliadins. In contrast to PEPs, naturally-evolved glutenases are resistant to digestion with pepsin and trypsin, and active over a large $\mathrm{pH}$ range. Further benefits are those they have a good safety profile, their isolation is very simple and they are widely used in malting industry for production of beer or baking ingredients (Stenman et al., 2009). Consequently, recent efforts focus on combination of appropriate $\mathrm{PEP} / \mathrm{s}$ with a naturally-evolved glutenases of complementary specificity.

In addition, other specific endopeptidases with cleavage activity for Pro-residues of different substrates have been reported, e.g. endopeptidase from Lactobacillus helveticus CNRZ32 (Chen et al., 2003), metalloendoproteinase from Penicillium citricum (Doi et al., 2004) and prolyl-endoprotease from Aspergillus niger (Stepniak et al., 2006). The latter one is promising tool for celiac disease therapy.

In our study we try to find another appropriate microbial proteases of different origin (bacterial either fungal) suitable for wheat gliadin hydrolysis. The proteolytic conditions for each enzyme were determined according enzyme databases available for free via internet (BRENDA, MEROPS). However, large complexity and high proline abundance makes wheat gliadins quite resistant to proteolysis, therefore further analysis is required.

\section{MATERIAL AND METHODS}

\section{Preparation of gliadins}

Wheat gliadins were prepared by discontinuous fractionation of cereal protein complex in two-step extraction using $10 \mathrm{ml}$ of solvent/g meal for 45 min under constant stirring at laboratory temperature. Extraction was carried out with $10 \%$ (v/v) $\mathrm{NaCl}$ to extract salt-soluble albumin/globulin fractions, and $70 \%(\mathrm{v} / \mathrm{v})$ ethanol to extract gliadins. Each extraction step was repeated three-times following by centrifugation. Supernatant containing wheat gliadins was concentrated using vacuum distillation and lyophilized.

\section{Enzymes used}

Fungal proteases from Aspergillus sp., Aspergillus oryzae and Aspergillus niger were supplied by Fluka (Switzerland). Bacterial proteases isolated from Bacillus licheniformis (Sigma, USA), Bacillus stearothermophilus (Fluka, Switzerland), Bacillus thermoproteolyticus (Fluka, Switzerland) and Streptomyces griseus 
(Fluka, Switzerland) formed the second group of enzymes used in this study. All commercially available enzymes were selected for their proteolytic activity to cleavage peptide bonds in various substrates. Specific conditions for each enzyme were determined according on-line enzyme databases (BRENDA, MEROPS).

\section{Proteolysis}

Lyophilized wheat gliadins $(1.5 \mathrm{mg})$ were dissolved in $150 \mu 1$ of appropriate reaction buffer with optimal $\mathrm{pH}$ for each enzyme (see Tab 1). Enzymes were Table 1 Summary of proteolytic conditions

\begin{tabular}{|c|c|c|c|c|c|}
\hline Protease & $\begin{array}{c}\text { Reaction } \\
\text { buffer }\end{array}$ & $\begin{array}{c}\text { Reaction } \\
\text { pH }\end{array}$ & $\begin{array}{c}\text { Reaction } \\
\text { temperature } \\
{\left[{ }^{\circ} \mathrm{C}\right]}\end{array}$ & Coenzyme & Inhibitor \\
\hline EC 3.4.21.63 (Aspergillus sp.) & $0.1 \mathrm{M}$ Tris- $\mathrm{HCl}$ & 8.5 & 55 & - & Pefablock $^{1}$ \\
\hline EC 3.4.24.39 (Aspergillus oryzae) & $\begin{array}{l}0.1 \mathrm{M} \text { acetate } \\
\text { buffer }\end{array}$ & 4.5 & 55 & $\mathrm{Zn}^{2+}$ & EDTA \\
\hline EC 3.4.23.19 (Aspergillus niger) & $\begin{array}{l}0.1 \mathrm{M} \text { citrate } \\
\text { buffer }\end{array}$ & 3 & 55 & - & Pepstatin $^{2}$ \\
\hline EC 3.4.21.62 (Bacillus licheniformis) & $0.1 \mathrm{M}$ Tris- $\mathrm{HCl}$ & 9 & 70 & - & Pefablock ${ }^{1}$ \\
\hline EC 3.4.21.62 (Bacillus stearothermophilus) & $0.1 \mathrm{M}$ Tris- $\mathrm{HCl}$ & 8 & 70 & - & Pefablock ${ }^{1}$ \\
\hline EC 3.4.24.27 (Bacillus thermoproteolyticus) & $0.1 \mathrm{M}$ Tris- $\mathrm{HCl}$ & 8 & 70 & $\mathrm{Zn}^{2+}$ & EDTA \\
\hline EC 3.4.24.31 (Streptomyces griseus) & $0.1 \mathrm{M}$ Tris- $\mathrm{HCl}$ & 8 & 37 & $\mathrm{Zn}^{2+}$ & EDTA \\
\hline
\end{tabular}

prepared in concentration $0.5 \mathrm{mg} / \mathrm{ml}$ in solution with the opposite $\mathrm{pH}$ level to reaction buffer $(50 \mathrm{mM}$ acetate buffer $\mathrm{pH} 5.5$ or $0.1 \mathrm{M}$ Tris- $\mathrm{HCl} \mathrm{pH} 8.0)$ Proteolysis was performed in enzyme:gliadins ratio 1:100 for fungal proteases and 1:250 for bacterial proteases in temperature conditions appropriate for each enzyme. In case of metallopeptidases, coenzyme $\mathrm{Zn}^{2+}$ in form of $\mathrm{ZnCl}_{2}$ was added to the reaction mixture. Proteolysis was stopped after 15, 30 and $60 \mathrm{~min}$ with suitable inhibitor. The conditions for each protease are listed in Table 1.

-(2-aminoethyl)-benzensulfonyl-fluoride, hydrochloride (AEBSF)

2 (3S, 4S)-4-amino-3-hydroxy-6-methylheptanoic acid

\section{SDS-PAGE}

Degree of hydrolysis and determination of molecular weights of peptides were done by SDS-PAGE under reducing conditions according to the Schägger-von Jagow method (Schägger and von Jagow, 1987).

\section{RESULTS}

\section{Proteolysis with fungal proteases}

Protease from Aspergillus niger (acid proteinase, aspergillopepsin II, EC 3.4.23.19) preferentially cleaved peptide bonds formed by amino acid Asn, Gln Gly, Ala, Tyr and Thr. Serine endopeptidase isolated from Aspergillus sp. (generally called alkaline protease) belonging to the category EC 3.4.21.63 hydrolyze proteins with broad specificity but does not hydrolyze peptide amides The last fungal protease used was metallopeptidase from Aspergillus oryzae (EC 3.4.24.39, also called deuterolysin) with capability to hydrolyze bonds with hydrophobic residues in P1' (MEROPS, BRENDA).

Although all fungal proteases coming from the same genus: Aspergillus, they show different pattern of proteolytic activity on wheat gliadins as a substrate Most effective proteolytic activity was observed using acid proteinase from $A$. niger since wheat gliadins and low molecular weight peptides were completely degraded (figure 1). In case of protease from $A$. $s p$. and $A$. oryzae, two product of $<15 \mathrm{kDa}$ were detected means that those examined endopeptidases are less efficient in cleavage of large peptides and intact proteins.

\section{Proteolysis with bacterial proteases}

Both serine proteases used are generally called subtilisins and has classification number EC 3.4.21.62, although coming from two different microorganisms: Bacillus licheniformis and Bacillus stearothermophilus. Subtilisins are nonspecific peptidases with affinity for the hydrophobic amino acid residues in the peptide chain of substrate so they hydrolyze bonds formed by amino acids Ala Leu, Ser, but also Val, Tyr, Phe, Gln, His (MEROPS, BRENDA). Another enzyme used in the study was metallopeptidase from Bacillus thermoproteolyticus (thermolysin, EC 3.4.24.27). Thermolysin has a high specificity for a hydrophobic amino acid residues, and hydrolyses mostly between residues P1-P1', where P1 is the residue derived from any hydrophobic amino acid and P1' is Leu, Phe, Ile or Val. Metallopeptidase from Streptomyce griseus (EC 3.4.24.31, commonly called mycolysin, pronase or actinase E), preferentially performs cleavage of peptide bonds with hydrophobic residues in P1' (MEROPS, BRENDA).

The main subfraction of wheat gliadins is $\alpha$-gliadin monomer with molecular weight of approx. $35 \mathrm{kDa}$ and consisting from several celiac-active epitopes. During proteolysis with peptidase from $B$. licheniformis and $B$ thermoproteolyticus this fraction was easily hydrolyzed and almost completely degraded to low molecular weight peptides of $<15 \mathrm{kDa}$. In case of serine

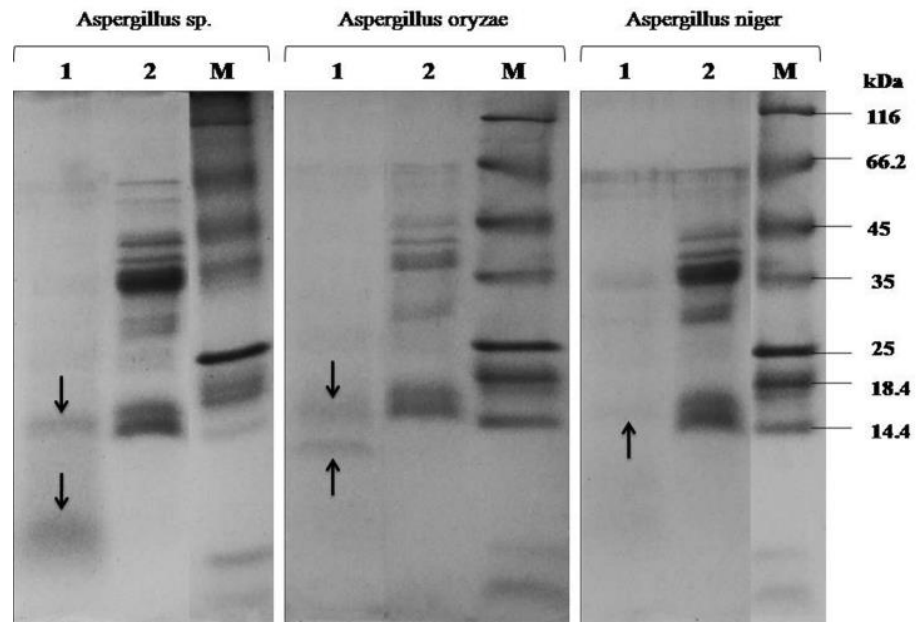

Figure 1 Determination of molecular weights of wheat gliadins and degree of hydrolysis by SDS-PAGE after $60 \mathrm{~min}$ of proteolysis using specific fungal proteases isolated from Aspergillus sp., Aspergillus oryzae and Aspergillus niger. Lane 1: wheat gliadins treated using fungal proteases; lane 2: un-treated wheat gliadins; M: molecular marker; vertical arrows indicate peptides after hydrolysis.

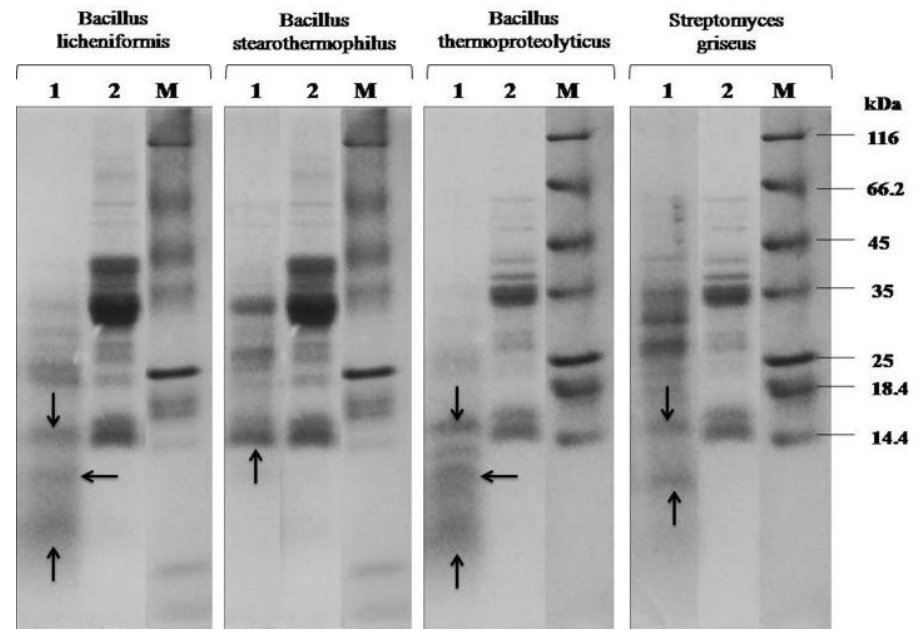

Figure 2 Determination of molecular weights of wheat gliadins and degree of hydrolysis by SDS-PAGE after $60 \mathrm{~min}$ of proteolysis using specific bacterial proteases isolated from Bacillus licheniformis, Bacillus stearothermophilus, Bacillus thermoproteolyticus and Streptomyces griseus. Lane 1: wheat gliadins treated using bacterial proteases; lane 2: un-treated wheat gliadins; M: molecular marker; vertical arrows indicate peptides after hydrolysis.

peptidase from B. stearothermophilus and metallopeptidase from $S$. griseus the pattern of proteolysis was not obvious as compare to B. licheniformis and $B$. thermoproteolyticus. On the one hand fragment of approx. $15 \mathrm{kDa}$ was occurred 
(in case of $S$. griseus another fragment with $<15 \mathrm{kDa}$ was observed), on the other hand gliadins of $35 \mathrm{kDa}$ were not completely hydrolyzed which means these two proteases act less effective. The degree of proteolytic degradation of wheat gliadins is shown in figure 2 .

\section{DISCUSSION}

Nowadays celiac disease is one of the most prevalent food intolerance worldwide causing by ingestion of wheat gliadins and corresponding proteins of rye, barley and possibly oat. The only treatment for celiac disease is a strict lifelong glutenfree diet. Alternative strategies to completely destroy or at least partially decrease the celiac activity of wheat gliadins are the subject of extensive research. These include exploration of ancient wheat (van den Broeck et al., 2010), inhibition of transglutaminase 2 (Maiuri et $\boldsymbol{a l}$., 2005), blocking of HLA-DQ2 to prevent binding of immunogenic peptides (Xia et al., 2007), prevention from immunogenic peptides through the tight junctions such as zonulin antagonists (Leffler $\boldsymbol{e t}$ al., 2012), induction of tolerance using anti-cytokines such as antiIFN- $\gamma$ (Bethune et al., 2009) or anti-IL-15 (Yokoyama et al., 2009) and using gluten tolerate vaccines (Anderson, 2008). Finally, the most promising alternative therapeutic approach seems enzymatic cleavage of gliadins using specific prolyl-endopeptidases (PEPs) of different origin, degradation of immunogenic peptides by germinating cereal enzymes and transamidation of cereal flour. In our work we have focused on cleavage capacity of novel specific endopeptidases of different origin (bacterial either fungal) which can serve as a potential tool to degrade wheat gliadins. Determination of protein hydrolysis and molecular weights of peptides was done by SDS-PAGE analysis.

Bacterial prolyl-endopeptidases due to their capability eliminate proline-reach gluten peptides have been investigated by Shan et al. (2004)

Such enzymes, including those from Flavobacterium meningosepticum (FM), Sphingomonas capsulate (SC) and Myxococcus xanthus (MX), efficiently degrade an $\alpha 2$-gliadin-derived 33-mer peptide highly resistant to digestion and could serve as oral supplementation. FM enzyme showed a preference for ProGln bonds, SC cleaved both Pro-Gln and Pro-Tyr bonds with comparable efficiency, and MX had a modest preference for Pro-(Tyr/Phe) sites over Pro-Gln sites (Shan et al., 2004). These prolyl-oligopeptidases are however not stable and functional under acidic conditions of the stomach and are unlikely to degrade gluten epitopes before they reach the small intestine (Matysiak-budnik $\boldsymbol{e t}$ al. 2005). In another study of Gass et al. (2007), a combination therapy of SC PEP and a glutamine-specific cysteine endoprotease (EP-B2) from barley was effective in degradation of clinically relevant quantities of gluten under gastric conditions. Bacterial endopeptidases isolated from the genus Bacillus used in our study mostly hydrolyze bonds formed by amino acids Ala, Leu, Ser, but also Val, Tyr, Phe, Gln, His. Nevertheless, they are not classified into prolyl-endopeptidase enzyme family, $35 \mathrm{kDa}$ wheat gliadins were susceptible to degradation, while low molecular weights products were appeared. However further analysis of such products is desirable.

Alternative enzyme derived from fungus Aspergillus niger (AN-PEP) is active between $\mathrm{pH} 2-8$, with an optimum activity at $\mathrm{pH} 4-5$, and is therefore effective in the stomach conditions. The enzyme is also not degraded by pepsin and thus remains fully functional. Another advantage of this enzyme is capability to degrade both whole gluten and gluten peptides into non-immunogenic residues within minutes (Stepniak et al., 2006; Mitea et al., 2008). From our three examined fungal endopeptidases (derived from Aspergillus sp., Aspergillus oryzae and Aspergillus niger), only the proteolysis using A. niger resulted in complete disappearing of $35 \mathrm{kDa}$ wheat gliadins and peptides with low molecular weights means that those examined endopeptidase are very efficient in cleavage of large peptides and intact proteins in contrast to previous fungal enzymes. The same conclusion was achieved by Stepniak et al. (2006). The authors measured efficiency of gluten degradation treated with AN-PEP and monitored the digestion process with mass spectrometry. Secondly, intact gluten digested with AN-PEP was separated by reverse-phase HPLC, than eluted fractions in specific time-points were separated onto SDS-PAGE gels followed by Western blotting with antibodies against gluten T cell epitopes. Proteolysis with AN-PEP resulted in complete degradation of both gliadin and glutenin molecules, and $\mathrm{T}$ cell epitopes in almost all cases. The data indicates that protease treatment, alone, should be considered as a potential tool for improving technological characteristics of flours.

\section{CONCLUSION}

The study was oriented toward proteolytic cleavage of wheat gliadins using microbial proteases. Gliadins were susceptible to proteolytic degradation of examined bacterial and fungal endopeptidases (exception were bacterial proteases from B. stearothermophilus and S. griseus), while products of low molecular weights $(<15 \mathrm{kDa})$ were appeared. From fungal proteases most effective proteolytic activity was observed using acid proteinase from A. niger since whea gliadins and low molecular weight peptides were completely degraded. Al bacterial proteases of different origin showed slight differences in the degree of proteolysis. B. licheniformis and B. thermoproteolyticus acted very effective and as the result of hydrolysis, the products of lower molecular weight $(<15 \mathrm{kDa})$ occurred. Although wheat gliadins are susceptible to enzymatic degradation, further analysis (e.g. immunochemical or mass spectrometry) are desirable to confirm if the products of proteolysis have lost or at least partially decrease their celiac activity.

Acknowledgments: This work was carried out with the financial support of project KEGA024SPU-4/2013.

\section{REFERENCES}

ANDERSON, R. P. 2008. Development of a vaccine for celiac disease. Fasano, A., Troncone, R., Branski, D. (eds): Frontiers in celiac disease. Pediatr Adolesc Med. Basel, Karger, 2008, 12, 172-180.

BETHUNE, M. T., SIEGEL, M., HOWLES-BANERJI, S., KHOSLA, CH. 2009 Interferon- $\gamma$ released by gluten-stimulated celiac disease-specific intestinal $\mathrm{T}$ cells enhances the transepithelial flux of gluten peptides. The Journal of Pharmacology and Experimental Therapeutics, 329(2), 657-668. http://dx.doi.org/10.1124/jpet.108.148007

van den BROECK, H. C., de JONG, H. C., SALENTIJN, E. M. J., DEKKING L., BOSCH, D., HAMER, R. J., GILISSEN, L. J. W. J., van der MEER, I. M., SMULDERS, M. J. M. 2010. Presence of celiac disease epitopes in modern and old hexaploid wheat varieties: wheat breading may have contributed to increased prevalence of celiac disease. Theoretical and Applied Genetics, 121, 1527-1539. http://dx.doi.org/10.1007/s00122-010-1408-4

CHEN, Y.-S., CHRISTENSEN, J. E., BROADBENT, J. R., STEELE, J. L. 2003. Identification and characterization of Lactobacillus helveticus PepO2, an endopeptidase with post-proline specificity. Applied and Environmental Microbiology, 69(2), 1276-1282. http://dx.doi.org/10.1128/AEM.69.2.12761282.2003

DOI, Y., AKIYAMA, H., YAMADA, Y., EE, CH. E., LEE, B. R., IKEGUCHI, M., ICHISHIMA, E. 2004. Thermal stabilization of penicillolysin, a thermolabile $19 \mathrm{kDa} \mathrm{Zn}^{2+}$-protease, obtained by site-directed mutagenesis. Protein Engineering, Design \& Selection, 17(3), 261-266. http://dx.doi.org/10.1093/protein/gzh034

EHREN, J., MORÓN, B., MARTIN, E., BETHUNE, M. T., GRAY, G. M., KHOSLA, CH. 2009. A food-grade enzyme preparation with modest gluten detoxification properties. PLoS ONE, 4(7), e6313. http://dx.doi.org/10.1371/journal.pone.0006313

GASS, J., BETHUNE, M. T., SIEGEL, M., SPENCER, A., KHOSLA, CH. 2007 Combination enzyme therapy for gastric digestion of dietary gluten in patients with celiac sprue. Gastroenterology, 133, 472-480. http://dx.doi.org/10.1053/j.gastro.2007.05.028

GREGORINI, A., COLOMBA, M., ELLIS, H. J., CICLITIRA, P. J. 2009 Immunogenicity characterization of two ancient wheat $\alpha$-gliadin peptides related to coeliac disease. Nutrients, 1(2), 276-290. http://dx.doi.org/10.3390/nu1020276

LEFFlER, D. A., KELlY, C. P., ABDAllaH, H. Z., COLATRELlA, A. M., HARRIS, L. A., LEON, F., ARTERBURN, L. A., PATERSON, B. M., LAN, Z. H., MURRAY, J. A. 2012. A randomized, double-blind study of larazotide acetate to prevent the activation of celiac disease during gluten challenge. The American Journal of Gastroenterology, 107, 1554-1562. http://dx.doi.org/10.1038/ajg.2012.211

MAIURI, L., CIACCI, C., RICCIARDELLI, I., VACCA, L., RAIA, V., RISPO, A., GRIFFIN, M., ISSEKUTZ, T., QUARATINO, S., LONDEI, M. 2005 Unexpected role of surface transglutaminase type II in celiac disease. Gastroenterology, 129 ,

MAKHARIA, G. K. 2014. Current and emerging therapy for celiac disease Frontiers in Medicine, 1(6), 1-11. http://dx.doi.org/10.3389/fmed.2014.00006 MAMONE, G., PICARIELLO, G., ADDEO, F., FERRANTI, P. 2011. Proteomic analysis in allergy and intolerance to wheat products. Expert Review of Proteomics, 8(1), 95-115. http://dx.doi.org/10.1586/epr.10.98

MARTI, T., MOLBERG, Ø., LI, Q., GRAY, G. M., KHOSLA, CH., SOLLID, L. M. 2005. Prolyl endopeptidase-mediated destruction of T cell epitopes in whole gluten: Chemical and immunological characterization. The Journal of Pharmacology and Experimental Therapeutics, 312(1), 19-26. http://dx.doi.org/10.1124/jpet.104.073312

MATYSIAK-BUDNIK, T., CANDALH, C., CELLIER, CH., DUGAVE, CH., NAMANE, A., VIDAL-MARTINEZ, T., CERF-BENSUSSAN, N., HEYMAN, M. 2005. Limited efficiency of prolyl-endopeptidase in the detoxification of gliadin peptides in celiac disease. Gastroenterology, 129, 786-796. http://dx.doi.org/10.1053/j.gastro.2005.06.016

MITEA, C., HAVENAAR, R., DRIJFHOUT, J. W., EDENS, L., DEKKING, L. KONING, F. 2008. Efficient degradation of gluten by a prolyl endoprotease in a gastrointestinal model: implications for coeliac disease. Gut, 57, 25-32. http://dx.doi.org/10.1136/gut.2006.111609

SCHÄGGER, H., von JAGOW, G. 1987. Tricine-sodium dodecyl sulfatepolyacrylamide gel electrophoresis for the separation of proteins in the range from 1 to $100 \mathrm{kDa}$. Analytical Biochemistry, 166(2), 368-379. 
SHAN, L., MARTI, T., SOLLID, L. M., GRAY, G. M., KHOSLA, CH. 2004. Comparative biochemical analysis of three bacterial prolyl endopeptidases: implications for coeliac sprue. Biochemical Journal, 383, 311-318. http://dx.doi.org/10.1042/BJ20040907

SIEGEL, M., BETHUNE, M. T., GASS, J., EHREN, J., XIA, J., JOHANNSEN, A., STUGE, T. B., GRAY, G. M., LEE, P. P., KHOSLA, CH. 2005. Rational design of combination enzyme therapy for celiac sprue. Chemistry \& Biology, 13 , 649-658. http://dx.doi.org/10.1016/j.chembiol.2006.04.009

SOLID, L. M., KHOSLA, CH. 2005. Future therapeutic options for celiac disease. Nature Clinical Practice Gastroenterology \& Hepatology, 2(3), 140-147. http://dx.doi.org/10.1038/ncpgasthep0111

STENMAN, S. M., VENÄLÄINEN, J. I., LINDFORS, K., AURIOLA, S. MAURIALA, T., KAUKOVIRTA-NORJA, A., JANTUNEN, A., LAURILA, K., QIAO, S.-W., SOLLID, L. M., MÄNNISTÖ, P. T., KAUKINEN, K., MÄKI, M. 2009. Enzymatic detoxification of gluten by germinating wheat proteases: Implications for new treatment of celiac disease. Annals of Medicine, 41, 390400. http://dx.doi.org/10.1080/07853890902878138

STENMAN, S. M., LINDFORS, K., VENÄLÄINEN, J. I., HAUTALA, A., MÄNNISTÖ, P. T., GARCIA-HORSMAN, J. A., KAUKOVIRTA-NORJA, A., AURIOLA, S., MAURIALA, T., MÄKI, M., KAUKINEN, K. 2010 Degradation of coeliac disease-inducing rye secalin by germinating cereal enzymes: diminishing toxic effects in intestinal epithelial cells. Clinical and Experimental Immunology, 161, 242-249. http://dx.doi.org/10.1111/j.13652249.2010.04119. $x$

STEPNIAK, D., SPAENIJ-DEKKING, L., MITEA, C., MOESTER, M., de RU, A., BAAK-PABLO, R., van VEELEN, P., EDENS, L., KONING, F. 2006. Highly efficient gluten degradation with a newly identified prolyl endoprotease: implications for celiac disease. American Journal of Physiology Gastrointestinal and Liver Physiology, 291, G621-G629. http://dx.doi.org/10.1152/ajpgi.00034.2006

VACCINO, P., BECKER, H. A., BRANDOLINI, A., SALAMINI, F., KILIAN, B. 2009. A catalogue of Triticum monococcum genes encoding toxic and immunogenic peptides for celiac disease patients. Molecular Genetics and Genomics, 281(3), 289-300. http://dx.doi.org/10.1007/s00438-008-0412-8

WIESER, H. 2007. Chemistry of gluten proteins. Food Microbiology, 24(2), 115 119. http://dx.doi.org/10.1016/j.fm.2006.07.004

XIA, J., BERGSENG, E., FLECKENSTEIN, B., SIEGEL, M., KIM, CH-Y., KHOSLA, CH., SOLLID, L. M. 2007. Cyclic and dimeric gluten peptide analogues inhibiting DQ2-mediated antigen presentation in celiac disease Bioorganic \& Medicinal Chemistry, 15, 6565-6573. http://dx.doi.org/10.1016/j.bmc.2007.07.001

YOKOYAMA, S., WATANABE, N., SATO, N., PERERA, P-Y., FILKOSKI, L., TANAKA, T., MIYASAKA, M., WALDMANN, T. A., HIROI, T. PERERA, L. P. 2009. Antibody-mediated blockade of IL-15 reverses the autoimmune intestinal damage in transgenic mice that overexpress IL-15 in enterocytes. Proceedings of the National Academy of Sciences, 106(37), 1584915854. http://dx.doi.org/10.1073/pnas.0908834106

ZINGONE, F., CAPONE, P., CIACCI, C. 2010. Celiac disease: Alternatives to a gluten free diet. World Journal of Gastrointestinal Pharmacology and Therapeutics, 1(1), 36-39. http://dx.doi.org/10.4292/wjgpt.v1.i1.36

MEROPS: The Peptidase Database, available at http://merops.sanger.ac.uk BRENDA: The Comprehensive Enzyme Information System, available at http://www.brenda-enzymes.org/ 